\title{
PPM USAHA KECIL BUBUK JAHE DI KELURAHAN KEPUTRAN KECAMATAN TEGALSARI KOTA SURABAYA
}

\author{
Ong Andre Wahyu Riyanto ${ }^{1}$, Astria Hindratmo², Muhammad Agung Setyawan ${ }^{3}$, Andi \\ Firman Baihaqi ${ }^{4}$ \\ ${ }^{1-4}$ Universitas Wijaya Putra
}

ongandre@uwp.ac.id, astriahindratmo@uwp.ac.id

\begin{abstract}
Abstrak
Usaha kecil bubuk jahe Bu Nining merupakan usaha yang dirintis sejak 3 tahun lalu yang tadinya digunakan untuk mencari pendapatan tambahan di waktu luang. Namun hingga saat ini usaha tersebut memiliki beberapa mengalami beberapa permasalahan seperti aspek produksi dimana kemasan tidak mempunyai lebel kemasan, proses pengemasan masih menggunakan bahan baku plastik yang tipis dengan perekat menggunakan media api dari lilin, dan tidak memiliki variasi ukuran produk hanya ukuran 200gr saja. Permasalahan aspek manajemen yaitu terkait manajemen pemasaran dimana mitra hanya menjual produk berdasarkan jumlah pesanan, permasalahan manajemen mutu juga belum ada penerapan, tidak adanya penerapan manajemen pengadaan bahan baku karena pembelian bahan baku seringkali menunggu ada pesanan. Tujuan dari kegiatan ini yaitu memberikan perbaikan pada aspek produksi dan manajemen guna meningkatkan jumlah produksi dan omset penjualan. Kegiatan ini memberikan pelatihan dan pendampingan perbaikan pada permasalahan yaitu terkait label kemasan, bahan kemasan, penggunaan alat press kemasan, pemasaran offline mapun online, penerapan manajemen mutu, dan pengadaan bahan baku. Hasil dari kegiatan yaitu mitra telah memiliki desain label pada kemasan, memiliki kemasan yang baik yang sehingga layak untuk di jual di toko oleh-oleh, serta telah mampu menjual pruduk secara online, memiliki konsep pemasaran offline yang baik, jumlah produksi dan penjualan meningkat.
\end{abstract}

Kata Kunci : Usaha Kecil, Pemasaran, Kemasan Produk.

\section{PENDAHULUAN}

Jahe merupakan rempah-rempah yang banyak di komsumsi orang untuk menghangatkan tubuh dan juga untuk digunakan sebagai jamu untuk kesehatan. Manfaat jahe yang sangat bagus, maka banyak produk makanan olahan jahe mulai dari minuman jahe hingga olahan berbentuk bubuk jahe. Salah satu usaha kecil pembuat bubuk jahe yang memiliki potensi untuk berkembang yaitu UMKM jahe milik $\mathrm{Bu}$ Nining yang terletak di dareah Dinoyo Kelurahan Keputran Kecamatan Tegalsari
Kota Surabaya.

Usaha bubuk jahe yang dimiliki oleh $\mathrm{Bu}$ Nining awal mulanya hanya di manfaatkan sebagai usaha sampingan untuk mengisi waktu luang di saat pulang kerja. Keahlian dalam membuat produk makanan dari tanaman herbal telah dilakukan oleh bu Nining sejak lulus sekolah, namun saat ini sudah fokus pada produksi bubuk jahe. Usaha Bubuk Jahe Bu Nining sudah dilakukan sejah 3 tahun yang lalu dan hingga sekarang penjualan bubuk Jahe semakin meningkat akibat permintaan yang selalu meningkat 
tiap tahun, apalagi saat pandemi Covid-19 permintaan bubuk jahe semakin banyak untuk digunakan sebagai minuman yang bermanfat meningkatkan daya tahan tubuh. Perkembangan usaha jahe ini terlihat dari jumlah omset sekitar 4 juta per bulan. Namun dalam menjalankan usahanya $\mathrm{Bu}$ Nining masih mengandalkan jumlah pesanan dari pemilik warung sekitar Dinoyo. Sehingga apabila tidak ada pesanan maka tidak melakukan produksi. Hal tersebut dikarenakan belum memiliki kerjasama ke toko-toko penjual minuman herbal dan juga belum memiliki konsep pemasaran tiap harinya. Selain itu juga karena adanya keterbatasan karyawan yang dimiliki yaitu hanya mempunyai 2 orang karyawan yang membantu memproduksi bubuk jahe. Karyawan tersebut merupakan tetangga sebelah rumah.

Berdasarkan hasil wawancara dengan pemilik dan observasi secara langsung, didapatkan 2 aspek permasalahan yaitu produksi dan manajemen. Pemasalahan aspek produksi yang menjadi prioritas untuk ditangani yaitu pada proses pengemasan dimana masih menggunakan kemasan plastik biasa yang tidak kedap udara. Hal tersebut mengakibatkan kualitas bubuk jahe kurang tahan lama. Mitra belum memiliki variasi ukuran produk Selain itu permasalahan berikutnya yaitu belum pengunakan peralatan Teknologi Tepat Guna pada proses pengemasannya. Padahal TTG bagi UKM sangat penting untuk memberikan rasa dibuat aman, nyaman, dan sehat saat bekerja sehingga dapat meningkatkan produktivitas kerja (Nurmianto, 2018).

Permasalahan aspek manajemen yang menjadi prioritas yaitu pada manajemen pengadaan bahan baku dimana proses pembelian bahan baku tidak terjadwal dengan baik. Menurut Wahyuni \& Syaichu (2015), untuk mengadakan kegiatan produksi, maka harus tersedia bahan baku yang baik dan sesuai dengan kebutuhan produksi perusahaan. Selain itu, mitra belum memiliki manajemen kualitas yang baik karena dalam proses produksinya tidak menggunakan sarung tangan dan masker agar produk lebih higienis. Selain itu permasalahan manajemen pemasaran dimana mitra kurang mampu membuat konsep pemasaran yang baik sehingga penjualan hanya mengandalkan pesanan dari tengkulak dan juga mitra belum memanfaatkan iklan online untuk mencari pelanggan baru. Menurut Kotler dan keller (2009) pemasaran yaitu suatu proses untuk mendapatkan, momunikasi serta memberi nilai pada pelanggan dengan maksud untuk keuntungan suatu organisasi. Strategi pemasaran yang optimal akan berpengaruh terhadap minat konsumen untuk membeli produk yang ditawarkan (Moniharapon et. al., 2015).

Tujuan dari kegiatan ini yaitu guna meningkatkan jumlah produksi dan omset penjualan dengan cara memberikan perbaikan pada aspek produksi dengan penerapan alat pres kemasan plastik (sealer), penggunaan kemasan plastik yang lebih tebal, dan perancangan desain label kemasan, dan menambah variasi produk. Selain itu juga memberikan perbaikan pada aspek manajemen pemasaran dengan merancang konsep marketing mix dan penentuan STP (Segmentation, Targeting, positioning) dan merancang iklan online melalui media sosial, serta pembuatan perencanaan bahan baku yang berkelanjutan dengan metode MRP (Material Requirement Planning) atau rencana kebutuhan material.

Rencana penanganan masalah yang ada pada mitra yaitu perbaikan pada aspek produksi dan manajemen untuk meningkatkan penjualan dan keuntungan mitra. Adapun detail rencana penaganan terdapat pada tabel 1 .

Tabel 1. Rencana Penaganan Masalah

\begin{tabular}{|c|c|c|}
\hline No & Permasalahan & Solusi \\
\hline \multirow{5}{*}{1.} & \multirow{5}{*}{ Produksi } & $\begin{array}{lll}\text { Pemberian } & \text { kemasan } & \text { plastik } \\
\text { vang tebal } & & \end{array}$ \\
\hline & & Penerapan alat pres pada \\
\hline & & kemasan \\
\hline & & Pembuatan \\
\hline & & $\begin{array}{l}\text { kemasan . } \\
\text { Pembuatan variasi ukuran } \\
\text { produk }\end{array}$ \\
\hline & & $\begin{array}{l}\text { Merancang konsep marketing } \\
\text { offline dan online. }\end{array}$ \\
\hline 2. & Manajemen & $\begin{array}{l}\text { Merancang rencana pengadaan } \\
\text { bahan baku dengan dengan } \\
\text { metode MRP. }\end{array}$ \\
\hline
\end{tabular}


Penerapan masker dan sarung tangan, menjaga kebersihan saat produksi.

Pengembangan metode penyelesaian masalah pada mitra yaitu dengan penerapan alat pres kemasan agar lebih kedap udara, merubah bahan baku kemasan jahe dengan plastik yang lebih tebal, serta memberikan label desain kemasan yang sesuai keinginan mitra dari yang sebelumnya tanpa mengunakan alat pres kemasasn dan tanpa label merek kemasan. Kemudian penyelesaian masalah manajemen mitra dilakukan penerapan manajemen pemasaran online dan offline, penerapan manajemen pengadaan bahan baku, penerapan penggunaan masker dan sarung tangan untuk menjaga kebersihan produksi.

\section{METODE}

Metode yang digunakan dalam menyelesaikan permasalahan mitra kegiatan pengabdian pada masyarakat pada UMKM jahe yaitu (1) observasi dan wawancara, (2) identifikasi masalah, (3) Pengambilan data terkait jenis plastik kemas bubuk jahe, (4) Pengambilan data dengan cara diskusi perancangan desain label merek bubuk jahe, (5) Pengambilan data dengan cara diskusi tentang penentuan variasi produk, (5) Mendesain alat pres untuk proses pengemasan.

Pelatihan dan pendampingan pada penyelesaian permasalahan produksi dengan pelatihan penggunaan alat pres kemasan (sealer) pada proses pengemasan, pelatihan pemilihan bahan baku kemasan yang cocok untuk bubuk jahe, pelatihan pembuatan desain label kemasan, pembuatan variasi ukuran produk. Kemudian pada penyelesaian permasalahan manajemen dengan pelatihan membuat konsep pemasaran secara online pada aplikasi media sosial dan konsep pemasaran secara offline dengan konsep marketing mix, pelatihan pembutaan prencanan bahan baku yang berkelanjutan dengan metode MRP, pelatihan penerapan sarung tangan dan masker pada tiap proses dalam produksi.

\section{HASIL DAN PEMBAHASAN}

\section{Pengguaan Plastik Kemas dengan yang lebih tebal (Standing Pouch Plastik Klip)}

Proses pengemasan yang dilakukan mitra sebelumnya mengunakan plastik jenis yang tipis, namun setelah dilakukan workshop tentang beberapa jenis platik kemas, akhirnya mitra menggunakan plastik kemas jenis standing pouch plastik klip.

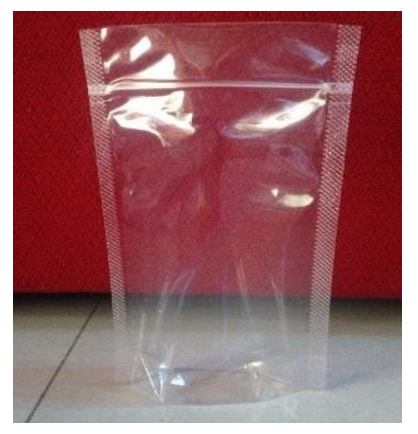

Gambar 1. Plastik Standing Pouch

\section{Hasil Penerapan alat Pres dalam Proses Pengemasan}

Pada saat proses pengemasan, mitra masih menggunakan plastik kemas yang tipis dan cara perekatan masih menggunakan pemanas dari lilin, sehingga hal tersebut modah sobek dan kurang kedap udara.

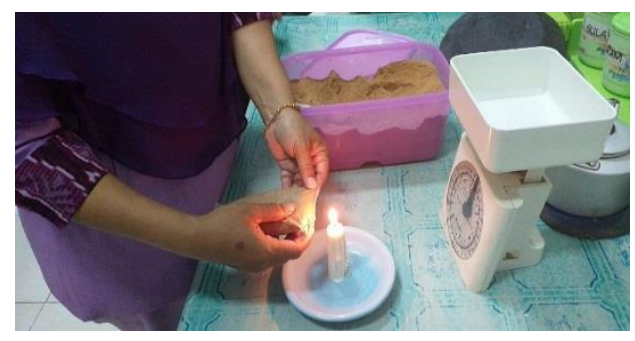

Gambar 2. Proses Perekatan Kemasan

Bila melihat proses perekatan yang dilakukan maka hal tersebut kurang kedap udara dan mudah sobek, sehingga perlu alat perekat yang lebih efektif dan hasilnya lebih kedap udara yaitu dengan pengunaan alat sealer (alat pres otomatis). 


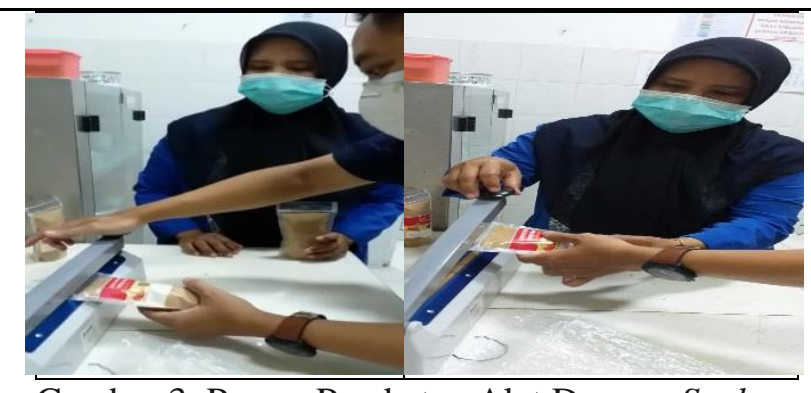

Gambar 3. Proses Perekatan Alat Dengan Sealer

\section{Hasil Pembuatan Desain Label Kemasan}

Mitra PKM sebelumnya dalam kemasan masih belum memiliki label pada kemasan. Berdasarkan hasil diskusi dengan pelatihan pembuatan desain label kemasan, maka saat ini mitra telah memiliki label kemasan yang menarik untuk di tempel di plastik kemasan.

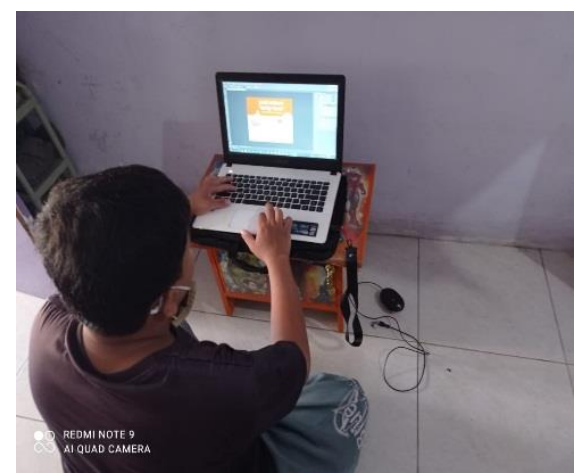

Gambar 4. Pelatihan Pembuatan desain Label

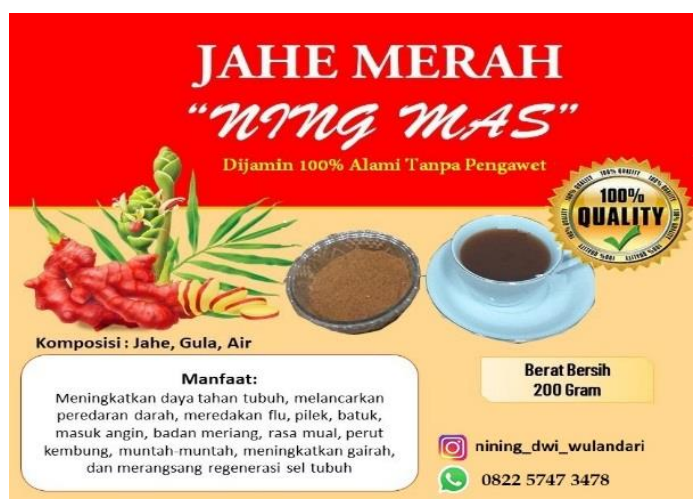

Gambar 5. Desain Label Kemasan Hasil Pelatihan

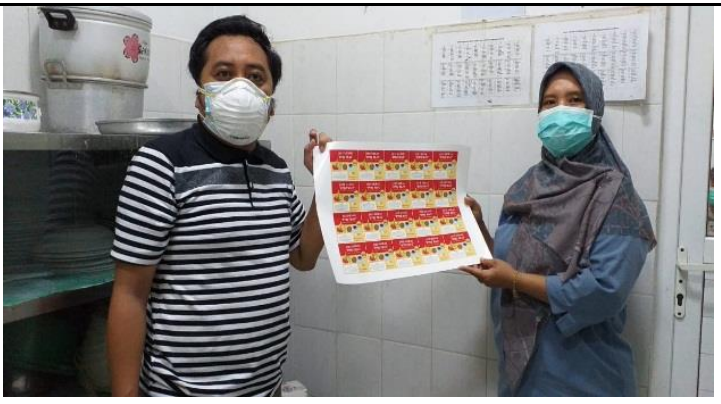

Gambar 6. Pemberiah Hasil Cetak Label Kemasan

\section{Hasil Pembuatan Variasi Produk}

Pembuatan variasi produk dilakukan untuk menyesuaikan beberapa segmentasi pembeli yang akan ditentukan agar penjualan meningkat. Selain itu juga untuk mendukung rencana penjualan online. Variasi yang dilakukan yaitu variasi ukuran produk yang akan di jual.
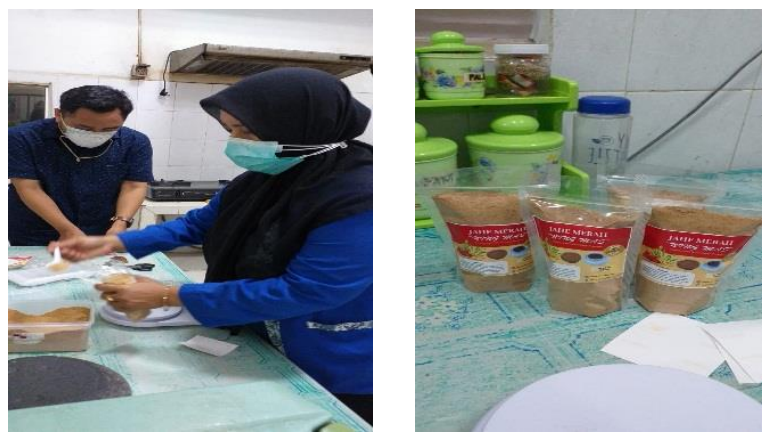

Gambar 7. Hasil Pelatihan Pembuatan Variasi Produk

\section{Hasil Perancangan Konsep Marketing Offline dan Online}

Pelatihan yang dilakukan pada mitra untuk merancang konsep marketing offline dan online di maksudkan agar penjualan produk bubuk jahe meningkat, lebih tepat sasaran, sesuai dengan target segmentasi ataupun target penjualan. Selain itu juga untuk menambah pemahaman kepada mitra akan pentingnya membuat konsep pemasaran. 


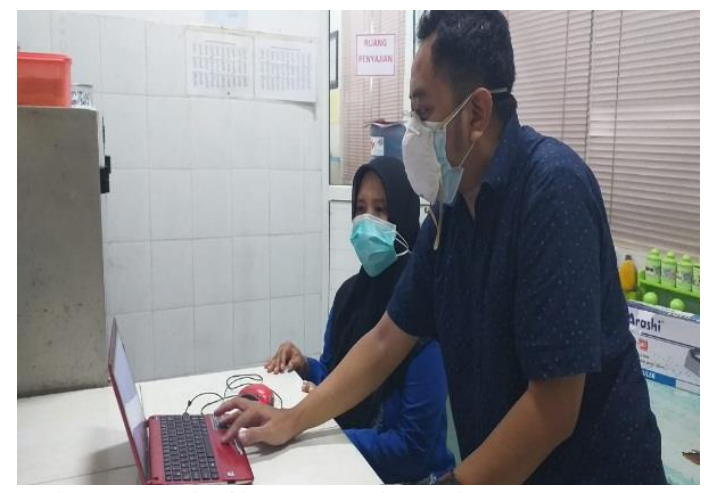

Gambar 8. Pelatihan membuat konsep Pemasaran

Tabel 2. Hasil Pelatihan Membuat Marketing Mix

\begin{tabular}{cccc}
\hline Produk & Price & Place & Promotion \\
\hline Ukuran & 20.000 & Toko & Media \\
$200 \mathrm{gr}$ & & $\begin{array}{c}\text { Oleh-oleh } \\
\text { \& Pasar }\end{array}$ & $\begin{array}{c}\text { Sosial \& } \\
\text { Kerjasama }\end{array}$ \\
\hline Ukuran & 10.000 & Pasar \& & Media \\
100 gr & & warkop & Sosial \& \\
& & & Kerjasama \\
\hline
\end{tabular}

Tabel 3. Penentuan STP

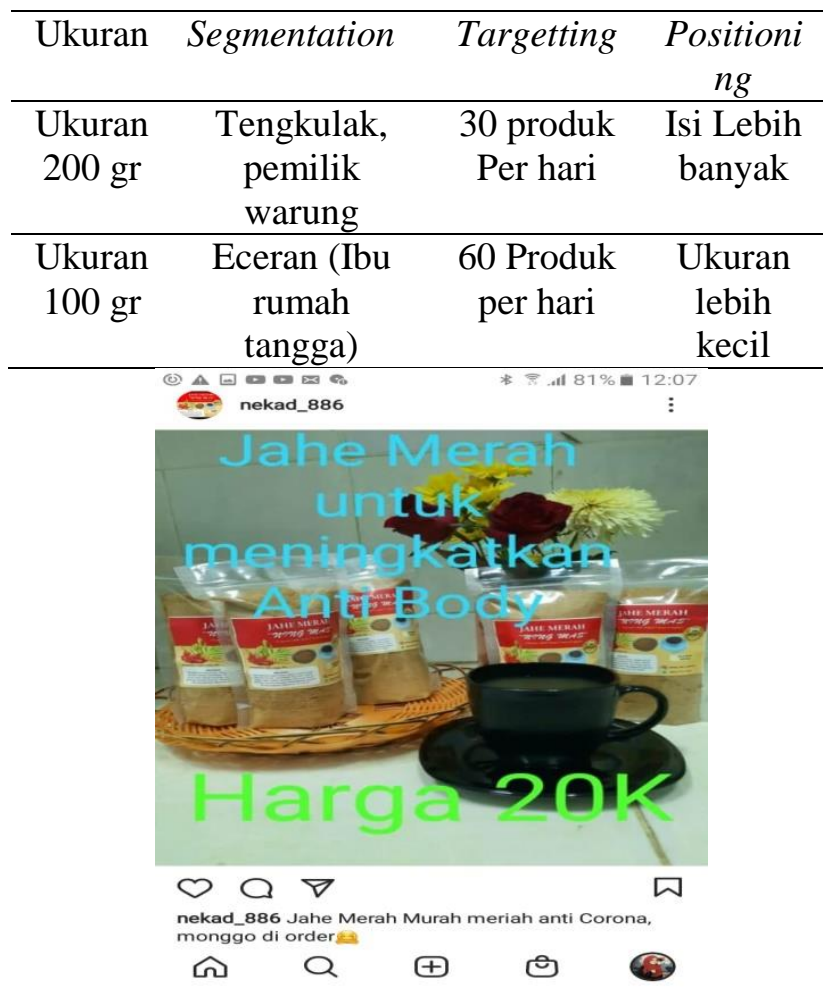

\section{Gambar 9. Hasil Pelatihan iklan Online}

\section{Hasil Perencanaan Kebutuhan Bahan Baku}

Pelatihan pembuatan perencanan bahan baku dilakukan agar mitra memiliki perencanaan pembelian bahan baku utama yaitu jahe merah. Selain itu juga dimaksudkan tidak terjadi pembelian bahan baku yang secara mendadak dan membuat biaya pembelian menjadi efisien karena harga jahe merah di pasaran cenderung tidak stabil. Pada Pelatihan ini mitra di latih prencanaan bahan baku dengan mengunakan metode MRP (Rencana Kebutuhan Material) dengan mengacu pada jadwal produksi dengan metode MPS (Master Production Scheduling). Pembuatan MRP dan MPS di buat secara sederhana untuk memudahkan mitra dalam membuat perencanaan bahan baku.

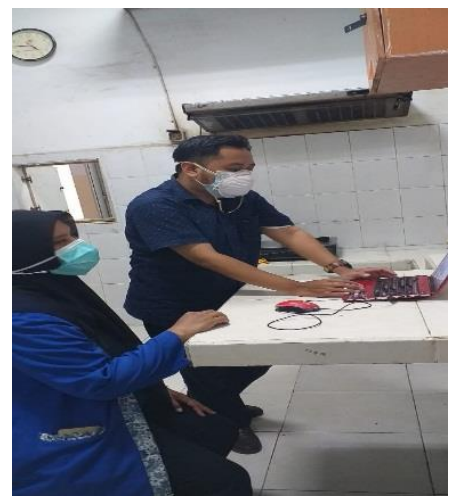

Gambar 10. Pelatihan Perencanaan bahan Baku

Tabel 2. Hasil Pelatihan Membuat Perencanan bahan Baku

\begin{tabular}{|c|l|c|c|}
\hline No & Periode & $\begin{array}{c}\text { MPS } \\
(\mathrm{Kg})\end{array}$ & $\begin{array}{c}\text { MRP } \\
(\mathrm{Kg})\end{array}$ \\
\hline 1 & Minggu ke-1 & - & 10 \\
\hline 2 & Minggu ke-2 & 10 & 15 \\
\hline 3 & Minggu ke-3 & 15 & 20 \\
\hline 4 & Minggu ke-4 & 20 & 15 \\
\hline 5 & Minggu ke-5 & 15 & 15 \\
\hline 6 & Minggu ke-6 & 15 & 20 \\
\hline 7 & Minggu ke-7 & 20 & 25 \\
\hline 8 & Minggu ke-8 & 25 & 15 \\
\hline 9 & Minggu ke-9 & 15 & - \\
\hline
\end{tabular}




\section{Hasil Penerapan Manajemen Mutu}

Pelatihan penerapan manajemen mutu di maksudkan untuk meningkatkan kebersihan produk karena produk merupakan jenis minuman berbentuk bubuk untuk kesehatan sehingga memerlukan produk higienis. Pada pelatihan ini mitra dibiasakan menggunakan masker, sarung tangan, serta selalu menjaga kebersihan dapur satt produksi.

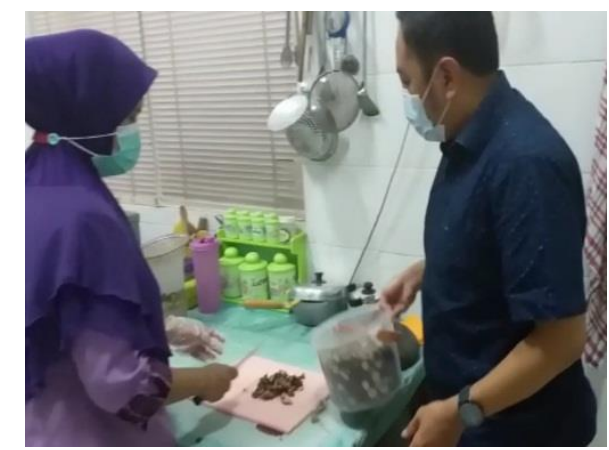

Gambar 11. Penerapan Manajemen Mutu

\section{KESIMPULAN}

Berdasrkan hasil kegiatan pengabdian dapat disimpulkan bahwa penggunaan alat pres kemasan (sealer) meningkatkan kualitas produk lebih tahan lama akibat lebih kedap udara. Pemberian desain label meningkatkan bentuk tampilan pruduk sehingga dapat di iklankan di media sosial. Penggunaan kemasan dengan material yang lebih tebal meningkatkan kualitas produk tidak mudah sobek dan lebih tahan lama. Penambahan variasi produk dapat meningkatkan penjualan serta lebih tepat sasaran ke segmentasi pembeli yang ditentukan mitra. Kemudian pelatihan manajemen pemasaran mampu membuat penjualan mitra lebih terkonsep dan tepat sasaran sehingga meningkatkan penjualan produk. Pelatihan manajemen bahan baku mampu membuat mitra lebih efektif dan efisien dalan pembelian dan biaya pembelian juga lebih efektif. Pelatihan penerapan manajemen mutu mampu meningkatkan kualitas produk lebih higienis.

\section{UCAPAN TERIMAKASIH}

Setelah berakhirnya kegiatan ini, maka kami ucapkan terima kasih kepada :

1. Ketua LPPM Universitas Wijaya Putra.
2. Dekan fakultas Teknik Universitas Wijaya Putra.

3. Ketua Program Studi Teknik Industri Universitas Wijaya Putra.

\section{REFERENSI}

Kotler \& Keller (2009). Manajemen Pemasaran Jilid I Edisi Ke 13 Jakarta: Erlangga.

Moniharapon, S., Oroh, Sem G., \& Ie, Herlin. (2015). Penerapan Strategi Promosi Pada Pemasaran Produk Federal Parts CV. Kanaka Jaya Manado. Jurnal EMBA, 3(2): 650-659.

Muhi Hanapiah A. (2009). Teknologi Tepat Guna (TTG) Dalam Perspektif Pemberdayaan Masyarakat, Institut Pemerintahan Dalam Negeri (IPDN),Jatinangor.

Nurmianto E. (2018). Pentingnya Ergonomi Teknologi Tepat Guna Di Bidang Industri, http://tbmkopel.or.id, diakses 20 April 2021,http://tbmkopel.or.id /2018/01/06/ ekonurmianto-pentingnya-ergonomteknologitepat-guna-di-bidang-industri/ .

Wahyuni, A. \& Syaichu, A. (2015). Perencanaan Persediaan Bahan Baku Dengan Menggunakan Metode Material Requirement Planning (MRP) Produk Kacang Shanghai Pada Perusahaan Gangsar NgunutTulungagung. Jurnal Spektrum Industri, 13(2):115 228. 